JURNAL ILMIAH KOMPUTERISASI AKUNTANSI, Vol. 14, No. 1,Juli 2021, pp.186 - 195

p-ISSN : 1979-116X (print)

e-ISSN : 2614-8870 (online)

http://journal.stekom.ac.id/index.php/kompak

- page 186

\title{
KETERKAITAN STRUKTUR KEPEMILIKAN, STRUKTUR MODAL DAN NILAI PERUSAHAAN
}

\section{Herry Subagyo}

Fakultas Ekonomi dan Bisnis, Universitas Dian Nuswantoro

Jl Nakula 1 No. 5-11 semarang, telp/fax (024) 3567010, e-mail: herry.subagyo @dsn.dinus.ac.id

ARTICLE INFO This research aims to test the relation between
Article history:

Received 30 Mei 2021

Received in revised form 2Juni2021

Accepted 10Juni2021

Available online 12Juli2021 ownership structures, and capital structure firm value of basic industry \& chemistry firm. This research places the capital structure as a mediating variable for the relationship between ownership structure and firm value. The sample used is a company listed on the Indonesia Stock Exchange for the period 2014-2019, using a porposive sampling technique obtained 115 samples that meet the criteria. Data processing using the IBM SPSS 23 series program as analysis tool. the result is that management's ownership has a negative effect on capital structure, and a positive effect on firm value, while institutional ownership has a positive effect on capital structure, and negative effect on firm value. This study also found that capital structure as a mediating variable of the relationship between management ownership and firm value.

Keywords: ownership structure, capital structure, firm value

ABSTRACT

1. Pendahuluan

Struktur modal merupakan salah satu keputusan strategis yang dilakukan oleh manajemen sebagai agen (agent), keputusan ini terkait dengan pemilihan alternati sumber pendanaan perusahaan, apakah menggunakan sumber dana dari kreditur atau sumber dana ekuitas (investor), keputusan ini akan menentukan struktur modal yang dapat mempengaruhi return dan risiko perusahaan [1]. Literatur keuangan menjelaskan, bahwa struktur modal adalah penggunaan sumber dana utang atau proporsi utang yang digunakan dalam membiayai aset perusahaan, selanjutnya, penggunaan utang tersebut dapat berdampak terhadap risiko perusahaan, semakin tinggi tingkat utang (leverage), semakin tinggi risiko. Disisi lain, penggunaan utang dapat berperan dalam menunjang operasional perusahaan yang dapat meningkatkan retun perusahaan. berdasarkan pada realitas tersebut penggunaan utang terkait dengan nilai perusahaan (Firm value), perusahaan yang mampu mengelola utangnya dengan benar pada waktu yang tepat, akan direspon oleh pasar melalui harga sahamnya, dan sebaliknya penggunaan utang yang berlebih akan meningkatkan risiko sehingga direspon negatif oleh pasar.

Keterkaitan utang dengan nilai perusahaan pertama kali dikenalkan oleh Franco Modigliani dan Melton Miller, menurutnya perusahaan yang menggunakan utang akan memperoleh penghematan pajak (tax saving), artinya, semakin banyak penggunaan hutang akan memperoleh penghematan pajak lebih tinggi, penghematan pajak yang berlangsung secara terus menerus sebagai kelebihan nilai perusahaan dari perusahaan unleverage [2]. Terkait dengan konsep tersebut, muncul pertanyaan, kenapa perusahaan tidak menggunakan hutang sebanyakbanyaknya? Benjawab permasalahan tersebut, [3] dalam konsepnya menjelaskan, bahwa setiap 
perusahaan memiliki tingkat penggunaan utangyang optimal, dan akan menyesuaikan tingkat utang riil kearah titik optimal. Titik optimal ini karena adanya penghematan pajak sebagai faktor yang mendorong penggunaan utang dan financial distress sebagai faktor yang membatasi penggunaan utang, selanjutnya konsep sebagaimana dikembangkan Stiglizt didukung dan dikembangkan oleh [4](4;5), dengan memasukan Cost of financial distress, Bunkruptsy dan Transaction cost, konsep ini dikenal dengan Theory of Balancing.

Isu lain terkait dengan struktur modal adalah faktor-faktor yang menentukan struktur modal, beberapa peneliti mencoba menguji faktor apa saja yang menjadi peratimbangan dalam menggunakan hutang. Faktor tersebut bisa dikelompokan dalam faktor mikroekonomi dan faktor makroekonomi. Faktor mikroekonomi adalah faktor yang bisa dikendalikan oleh manajemen, seperti profitabilitas, peluang investasi, ukuran perusahaan dan struktur kepemilikan. Sedangkan makroekonomi adalah kondidisi perokonomian seperti, tingkat bunga, nilai tukar, inflasi dan pertumbuhan ekonomi $(6 ; 7)$ Makroekonomi merupakan faktor yang tidak bisa dikendalikan manajemen, yang bisa dilakukan adalah menyesuaikan kebijakan utangnya dengan kondisi lingkungan makroekonomi tersebut.

Penelitian ini menggunakan faktor mikroekonomi yang bisa dikendalikan perusahaan, khususnya struktur kepemilikan yang mengacu pada teori keagenan dan tata kelolaan perusahaan. serta kaitanya dengan keputusan struktur modal dan nilai perusahaan. Penelitian struktur kepemilikan telah banyak dilakukan oleh peneliti sebelumnya, namun demikian penelitian tersebut kebanyakan hanya dikaitkan dengan nilai perusahaan, masih jarang yang mengkaitkan dengan keputusan struktur modal. Struktur kepemilikan dalam penelitian ini diproksi dengan kepemilikan saham manajemen (Managerial ownership) dan investor institusi (Institution ownership), dampaknya terhadap keputusan struktur modal dan nilai perusahaan. Beberapa penelitian sebelumnya yang telah dilakukan pada umumnya mengkaitkan struktur kepemilikan dengan tata kelola perusahaan [9] struktur kepemilikan dengan inovasi [10], struktur kepemilikan dengan merger dan akuisisi [11], dan investor institusi dengan portofolio perusahaan [12].

Kepemilikan saham manajemen merupakan jumlah saham yang dikusai oleh manajemen yang secara aktif terlibat dalam pengambilan keputusan dan operasional perusahaan. Dalam perspektif keagenan, pemilik perusahaan (Principal) dan manajemen (agent) terjadi konflik kepentingan, konflik tersebut muncul karena ada kencederungan manajemen dalam pengambilan keputusan tidak mengutamakan kepentingan pemelik perusahaan, tetapi mengutamakan kepentingan sendiri, keputusan-keputusan manajemen tersebut direfleksikan dalam struktur keuangan perusahaan, termasuk keputusan dalam struktur modal [13]. Salah satu cara agar manajemen mau bertindak sesuai dengan keinginan pemilik, adalah dengan kepemilikan saham manajemen. Kepemilikan saham manajemen tersebut dapat memotivasi manajemen untuk bertindak sesuai dengan kepentingan pemilik, karena manajemen bertindak sebagai pemilik perusahaan juga, bukti empirik menunjukan kebijakan utang tidak ada kaitanya dengan kepelikan saham manajemen apabila kedua pihak selaras, artinya manajemen akan mengabil keputusan penggunaan utang secara rasional dan bertindak sesuai dengan kepentingan pemilik [14]. Kerkaitan kepemilikan saham manajemen dengan kebijakan utang juga dapat dijelaskan dengan perspektif aliran kas bebas (Free Cash flows, dikatakan bahwa ada kecenderungan manajemen menggunakan aliran kas bebas, kas bebas adalah, kelebihan kas setelah dikurangan untuk investasi yang menhasilkan NPV positif pada tingkat bunga pasar yang relevan, kelebihan kas tersebut digunakan pada investasi yang tidak efisien, untuk itu manajemen harus dipaksa untuk menggunakan kas tersebut untuk membayar dividen, atau dengan cara yang lain, yaitu mengikat manajemen dengan menerbitkan utang, cara ini dimaksudkan agar manajemen terikat untuk membayar pokok dan bunga, dengan demikian kebijakan utang ini sebagai mekanisme kontrol [15], bukti empirik keterkaitan kepemilkan saham manajemen dengan kebijakan utang menemukan hubungan positif [16].

Keselarasan kepentingan pemilik perusahaan dengan manajemen sebagaimana telah dijelaskan mendorong manajemen bertindak sebagai pemilik hal ini berdampak positif pada nilai perusahaan. Keselarasan kepentingan pemilik perusahaan dengan manajemen sebagaimana telah dijelaskan mendorong manajemen bertindak sebagai pemilik hal ini berdampak positif pada nilai perusahaan, bukti empirik menunjukan bahwa kepemilikan saham manajemen berpengaruh positif terhadap nilai perusahaan [15;16;17]. Penelitian yang dilakukan oleh [20] menemukan hubungan yang tidak linier saham manajemen dengan nilai perusahaan. penelitian lain yang

JURNAL ILMIAH KOMPUTERISASI AKUNTANSI Vol. 14, No. 1, Juli 2021 : 186 - 195 
dilakukan oleh [21] menemukan bahwa kepemilikan saham manajemen memoderasi pengaruh intelectual capital dengan nilai perusahaan. Namun demikian, beberapa penelitian tidak menemukan hubungan saham manajemen dengan nilai perusahaan [22], namun demikian, penurunan kepemilikan saham manajemen yang cukup signifikan akan berdampak terhadap nilai perusahaan. berdasarkan bukti empirik tersebut dapat dipahami bahwa keterkaitan kepemilikan saham manajemen dengan nilai perusahaan tersebut tidak konsisten, tergantung pada dinamika yang terjadi dalam perusahaan [23].

Faktor lain yang diprediksi menentukan struktur modal dan nilai perusahaan adalah adalah kepemilikan saham oleh investor institusi (Institusional ownership), investor isntitusional adalah saham yang dimiliki oleh bukan individu tetapi perusahaan atau lembaga lain yang secara aktif mengontral aktivitas operasional perusahaan. Jumlah saham yang dimiliki oleh investor institusi ini umumnya relatih besar sehingga efektif dalam mengontrol pengambilan keputusan keuangan perusahaan, seperti diketahui investor instutusi merupakan sekelompok investor yang pada umumnya memiliki pengalaman dan jaringan bisnis yang luas sehingga mampu menganalisis dan menilai keputusan-keputusan dan portofolio bisnis yang dibuat oleh manajemen [24], Investor institusi sangat berperan sebagai pemain yang penting dalam pasar modal baik dinegaranya maupun di negara lain, investor institusi ini pada umumnya dapat melakukan pengawasan yang lebih efektif, sehingga dapat mempengaruhi harga saham [25]. Terkait dengan kebijakan utang, investor institusi ini sangat efektif dalam melakukan pengawasan termasuk keputusan dalam menentukan kebijakan utang [26]. Bukti empirik keterkaitan investor institusi dengan struktur modal dan nilai perusahaan menyatakan bahwa investor institusi berpengaruh positif terhadap nilai perusahaan tetapi tidak ada pengaruhnya terhadap struktur modal [26], temuan yang lain menyatakan bahwa nilai perusahaan berpengaruh positif dengan nilai perusahaan [27]. sedangkan temuan yang berbeda menyatakan bahwa investor institusi tidak secara langsung berpengaruh dengan nilai perusahaan [28], invesrtor insitusi tidak berpengaruh terhadap nilai perusahaan [29]. Sementara itu, [25] [30] menemukan hubungan terbalik antara invetor institusi dengan struktur modal. Bukti empirik keterkaitan investor institusi dengan struktur modal dan nilai perusahaan menunjukan hasil yang tidak konsisten, atas dasar hasil temuan yang inkonsisten tersebut penelitian ini mencoba ulang dan menganalisis menganalisis faktor penyebab inskonsistensi keterkaitan struktur kepemilikan dengan struktur modal dan nilai perusahaan.

Penelitian ini menggunakan sample perusahaan yang tergabung dalam subsektor Industri dasar dan Kimia Bursa Efek Indonesia, obyek ini dipilih karena memiliki kinerja keuangan yang stabil selama periode pengamatan sehingga tepat sebagai obyek penelitian. Penelitian ini menempatkan struktur modal sebagai variabel mediasi, kepemilikan saham manajemen dan kepemilikan saham investor institusi sebagai variabel independen, sedangkan Nilai perusahaan ditempatkan sebagai variabel independen.

Konsep keagenan menjelaskan bahwa kepemilikan saham dapat mengurangi konflik keagenan antara pemilik dengan keagenan, karena adanya kepentingan yang yang selaras. Bukti empirik keterkaitan kepemilikan saham manajemen dengan struktur modal dan nilai prusahaan dikemukakan oleh [31], bahwa kepemilikan saham manajemen dapat mengeleminasi konflik kepentingan antara pemegang saham dan manajemen, temuan ini sejalan dengan konsep keagenan yang dikemukakan oleh [13] bahwa ada kecenderungan konflik antara pemegang saham dengan manajer, konflik tersebut muncul karena adanya kepentingan yang tidak selaras. Selanjutnya, dijelaskan pula, bahwa kepemilikan saham manajemen dapat mengeleminasi konflik, karena manajemen juga sebagai pemilik perusahaan, Keselarasan tersebut selanjutnya dapat berdampak pada keputusan yang diambil termasuk kebijakan utang, [32]. Selanjutnya dijelaskan pula bahwa kebijakan utang dapat mengurangi agency problem, artinya perusahaan dapat mengkombinasikan insider ownership dan kebijakan utang guna meminimalkan agency cost. Hasil penelitian yang telah dilakukan sebelumnya menunjukan bahwa kepemilikan saham manajemen berpengaruh positif terhadap nilai perusahaan [26;17], Sedangkan keterkaitan antara kepemilikan saham manajemen dengan struktur modal dijelaskan oleh [33];[34][35] bahwa kepemilikan saham manajemen

KETERKAITAN STRUKTUR KEPEMILIKAN, STRUKTUR MODAL DAN NILAI PERUSAHAAN 
memiliki efek negatif pada leverage. Berdasarkan hubungan tersebut, maka hipotesis yang diajukan adalah:

$\mathrm{H} 1$ : Kepemilikan saham manajemen berpengaruh negatif terhadap Struktur Modal

$\mathrm{H} 2$ : Kepemilikan saham manajemen berpengaruh positif terhadap Nilai Perusahaan

institusi

Keterkaitan investor institusi dengan struktur modal dan nilai perusahaan, investor

adalah saham yang dimiliki oleh perusahaan lain atau lembaga lain yang secara aktif mengontral aktivitas operasional perusahaan, Jumlah saham yang dimiliki oleh investor institusi ini umumnya relatih besar sehingga efektif dalam mengontrol pengambilan keputusan keuangan perusahaan, seperti diketahui investor instutusi merupakan sekelompok investor yang pada umumnya memiliki pengalaman dan jaringan bisnis yang luas sehingga mampu menganalisis dan menilai keputusan-keputusan dan portofolio bisnis yang dibuat oleh manajemen. Investor institusi sangat berperan sebagai pemain yang penting dalam pasar modal baik dinegaranya maupun di negara lain dan dapat melakukan pengawasan yang lebih efektif yang akan mempengaruhi harga saham [25], dan keputusan dalam menentukan struktur modal [26]. Bukti empirik keterkaitan investor institusi dengan nilai perusahaan menunjukan adanya pengaruh positif [36]. Sedangkan kaitan antara investor institusi dengan struktur modal menyatakan bahwa investor institusi berpengaruh negatif terhadap struktur modal [22;32;25]. Berdasarkan penjelasan tersebut, penelitian ini mengajukan hipotesis:

H3 : Investor institusi berpengaruh negatif dengan struktur modal.

$\mathrm{H} 4$ : Investor institusi berpengaruh positif terhadap nilai perusahaan.

Konsep aliran kas bebas (Free Cash flows) menyatakan bahwa ada kecenderungan manajemen menggunakan aliran kas bebas diinvestasikan pada investasi yang tidak meningkatkan kesejahteraan pemilik, kas tersebut akan lebih baik dibayarkan sebagai dividen. Untuk menghindari penggunaan kas tersebut, manajemen harus diikat dengan dipaksa menerbitkan utang, cara ini dimaksudkan agar manajemen terikat untuk membayar pokok dan bunga, dengan demikian kebijakan utang ini sebagai mekanisme kontrol [38]. Keterkaitan struktur modal dengan nilai perusahaan juga bisa dijelaskan dengan Signaling theory, bahwa pemegang saham luar dan manajemen tidak memiliki akses informasi yang sama, adanya informasi yang tidak simetris (asymetric information) tersebut. ketika diterbitkan utang baru direspon oleh pemegang saham sebagai signal prospek yang positif yang dapat meningkatkan nilai perusahaan[39]. Bukti empirik keterkaitan truktur modal dengan nilai perusahaan menunjkan bahwa struktur modal berpengaruh positif terhadap nilai perusahaan [34;35;36]. Berdasarkan keterkaitan struktur modal dengan nilai perusahaan diajukan hipotesis:

H5 : Struktur Modal berpengaruh positif terhadap nilai perusahaan.

\section{Metode Penelitian}

Desain penelitian ini menempatkan struktur modal (CAPS) sebagai variabel mediasi, variabel kepemilikan saham manajemen (INSD) dan investor institusi (INST)sebagai variabel independen, sedangkan nilai perusahaan (Q) ditempatkan sebagai varibel dependen. Sample yag digunakan adalah perusahaan yang tergabung pada sub sektor Industri Dasar dan Kimia Bursa Efek Indonesia tahun 2013-2017. Teknik sampling yang digunakan adalah porposive sampling dengan kriteria 1) Perusahaan yang yang secara rutin mebuat laporan keuangan selama periode pengamatan, 2) Perusahaan yang memiliki saham manajemen dan investor instittusi. Berdasarkan kriteria tersebut terdapat 115 sample. Penelitian ini menggunakan alat analisi regresi berganda.

\section{Difinisi Operasional.}

Penelitian ini menggunakan difinisi operasional dan indikator pengukuran varibel seperti terlihat dalam Tabel I, Kepemilikan saham manajemen (INSD) adalah persentasi saham yang dimiliki oleh direksi, manajer dan eksekutif perusahaan. Kepemilikan saham Investor Intitusi (INST) adalah Persentase saham yang dimiliki oleh perusahaan lain, lembaga keuangan dan perusahaan pemerintah, Struktur Modal (CAPS) adalah Proporsi utang jangkan panjang yang digunakan untuk membiayai operasional perusahaan (leverage). Nilai

JURNAL ILMIAH KOMPUTERISASI AKUNTANSI Vol. 14, No. 1, Juli 2021 : 186 - 195 
Perusahaan (Q) Persepsi investor terhadap kemampuan perusahaan dalam mengelola sumber daya yang dicerminkan dalam harga saham

Tabel I

Difinisi operasional variabel:

\begin{tabular}{|c|c|c|c|}
\hline No & Variabel & Difinisi operasional & Indikator \\
\hline 1 & $\begin{array}{l}\text { Kepemilikan } \\
\text { Saham } \\
\text { Manajemen } \\
\text { (INSD) }\end{array}$ & $\begin{array}{l}\text { Persentase dari saham yang } \\
\text { dimiliki oleh direksi, manajer } \\
\text { dan eksekutif perusahaan [19]. }\end{array}$ & $\mathrm{INSD}=\frac{\text { Saham Manajemen }}{\text { Total lembar saham }}$ \\
\hline 2 & $\begin{array}{l}\text { Investor } \\
\text { institusi (INST) }\end{array}$ & $\begin{array}{l}\text { Persentase saham yang dimiliki } \\
\text { oleh perusahaan lain, lembaga } \\
\text { keuangan dan perusahaan } \\
\text { pemerintah [19]. }\end{array}$ & INST $=\frac{\text { Saham Investor }}{\text { Total lembar saham }}$ \\
\hline 3 & $\begin{array}{l}\text { Struktur Modal } \\
\text { (CAPS) }\end{array}$ & $\begin{array}{l}\text { Proporsi utang jangkan panjang } \\
\text { yang digunakan untuk } \\
\text { membiayai operasional } \\
\text { perusahaan (leverage),[37;1] }\end{array}$ & CAPS $=\frac{\text { Utang Jangka panjang }}{\text { Total Aset }}$ \\
\hline 4 & $\begin{array}{l}\text { Nilai } \\
\text { Perusahaan } \\
\text { (Q) }\end{array}$ & $\begin{array}{l}\text { Persepsi investor terhadap } \\
\text { kemampuan perusahaan dalam } \\
\text { mengelola sumber daya yang } \\
\text { dicerminkan dalam harga } \\
\text { saham [15]. }\end{array}$ & $\begin{array}{l}\mathrm{Q}=(\mathrm{E}+\mathrm{D}) / \mathrm{A} \\
\text { Dimana }: \\
\mathrm{E}=\text { Nilai pasar modal sendiri } \\
\text { (market value of equity ). } \\
\mathrm{D}=\text { Utang (Debt) } \\
\mathrm{A}=\text { Aset (Assets) }\end{array}$ \\
\hline
\end{tabular}

Alat Analisis.

Alat analisis yang digunakan dalam penelitian ini adalah Regresi berganda, alat ini digunakan untuk mengetahui dan mengukur apakah variabel indepenpenden ISND, INST, dan CAPS secara statististik mempengaruhi variabel dpenden $Q$, pada level yang ditetapkan $(5 \%)$. Program statitik yang digunakan adalah IBM SPSS seri 23. Persamaan regresi diformulasikan sebagai berikut:

2.1 Uji Regresi.

$$
\begin{aligned}
& \text { CAPS }=\alpha_{1}+\beta_{1} \text { INSD }+\beta_{2} \text { INST }+e_{1} \\
& Q=\alpha_{2}+\beta_{3} \text { INSD }+\beta_{4} \text { INST }+\beta_{5} \text { CAPS }+e_{2}
\end{aligned}
$$

Keterangan:

$$
\begin{array}{ll}
\text { INSD } & =\text { Kepemilikan saham Manajemen } . \\
\text { INST } & =\text { Kepemilikan saham Institusi. } \\
\text { CAPS } & =\text { Struktur Modal. } \\
\text { Q } & =\text { Nilai Perusahaan. }
\end{array}
$$

\subsection{Uji Mediasi.}

Untuk menguji apakah variabel struktur modal memediasi pengaruh kepemilikan saham manajemen (INSD) dan Kepemilikan saham Institusi (INST), menggunakan Sobel test dengan persamaan sebagai berikut:

$$
z \text {-value }=a^{*} b / S Q R T\left(b^{2 *} S_{a}^{2}+a^{2 *} s^{2}+S_{a^{2 *}}{ }^{2} b^{2}\right)
$$

Keterangan :

KETERKAITAN STRUKTUR KEPEMILIKAN, STRUKTUR MODAL DAN NILAI PERUSAHAAN 
$a=$ koefisien regresi (unstandardized), hubungan variabel independen (INSD, INST) dengan variabel mediasi (CAPS).

$S_{\mathrm{a}}=$ standard error dari koefisien regresi (a).

$b=$ Koefisien regresi (unstandardized) variabel (CAPS) dengan dependen variabel $(\mathrm{Q})$

$s_{\mathrm{b}}=$ Standard error dari $b$.

\section{Hasil dan Pembahasan}

Tabel II merupakan statistik deskreptif variabel yang berisi deskripsi tentang nilai minimum, nilai maksimum, nilai rata-rata $(M e a n)$ dan standar deviasi dari seluruh variabel yang digunakan dalam model penelitian ini, hasil output statistik deskriptik variabel INSD nilai minimum 0,01 , dan nilai maksimum 33,84 , nilai rata-rata 6,65 dengan deviasi standar 7,45 , nilai ini menggambarkan adanya sebaran atau variasi data kepemilikan saham manajemen cukup tinggi karena nilai deviasi standar lebih besar dari nilai rata-rata. Variabel INST nilai minimal 19,6 dan nilai maksimum 89,47 , nilai rata-rata 50,34 dengan deviasi standar 22,78 . Nilai ini bisa disimpulkan bahwa INST sebaranya relatif rendah dari nilai rata-rata. Variaabel CAPS nilai minimal $-3,18$, nilai maksimum 50,97, nilai rata-rata 12.44 dengan standar deviasi1,51,angka ini menunjukan data struktur modal variasinya relatif rendah. Nilai minimum variabel nilai perusahaan -0,69 dan nilai maksimumnya 6,43 dengan nilai rata-ratanya 1,39 sedangkan standar deviasinya 1,49 , apabila dilihat dari nilai rata-ratanya menunjukan bahwa nilai perusahaan > 1 yang maknanya bahwa perusahaan disektor industri dasar dan kimia cenderung mengalami pertumbuhan yang cukup baik, hal ini bisa dilihat dari nilai pasarnya lebih tinggi dari nilai bukunya.

\section{Tabel II Statistik Deskriptif}

\begin{tabular}{crrrrr}
\hline Variabel & N & Minimum & \multicolumn{1}{c}{ Maximum } & \multicolumn{1}{c}{ Mean } & Std Deviation \\
\hline INSD & 115 & .01 & 33,84 & 6.65 & 7.45 \\
INST & 115 & 19,6 & 89,47 & 50.34 & 22.76 \\
CAPS & 115 & -3.18 & 50,97 & 12.44 & 1.51 \\
Q & 115 & $-0,69$ & 6,43 & 1.39 & 1.49 \\
\hline
\end{tabular}

Sumber: data diolah

Tabel III seperti terliht dibawah merupakan hasil uji hepotesis model regresi (1) yng menempatkan Struktur modal (CAPS) sebagai variabel dependen, dan variabel kepemilikan saham manajemen (INSD) serta Kepemilikan saham investor institusi (INST) sebagai variabel independen. Keterkaitan. Keterkaitan antara variabel independen dengan varibel dijelaskan sebagai berikut.

\subsection{Hubungan Kepemilikan Saham Manajemen dengan Struktur Modal.}

Penelitian ini memprediksi kepemilikan saham manajemen berpengaruh terhadap struktur modal seperti terlihat dalam statemen Hipotesis $(\mathrm{H} 1)$, prediksi ini didasari pada konsep keagenan yang menjelaskan bahwa kepemilikan saham oleh manajemen akan memotivasi manajemen untuk bertindak sebagai pemilik perusahaan, dengan bertindak sebagai pemilik manajemen akan lebih berhati hati dan bertindak rsional, termasuk dalam penerbitan surat utang. Berdasarkan hasil uji hepotesis seperti terlihat dalam Tabel III, Nilai konstatnta 0,378 dengan nilai signifikansi $0,351>0,05$ yang maknanya nilai konstanta tidak signifikan. Koefisien regresi INSD -,052 dengan nilai signifikasi $0,028<0,05$, dengan demikian secara statistik kepemilikan saham manajemen berpengaruh terhadap kebijakan struktur modal, nilai negatif dari koefisien ini menunjukan hubungan terbalik seperti yang dinyatakan dalam hipotesis, dengan demikian hasil penelitian sesuai dengan prediksi sebelumnya yang dinyatakan dalam hipotesis $(\mathrm{H} 1)$ bahwa kepemilikan saham manajemen berpengaruh negatif terhadap struktur modal, temuan ini mendukung penelitian sebelumnya yang dilakukan oleh [35][34][33]. Temuan ini mengindikasikan bahwa manajemen di sektor Industri Dasar dan Kimia cenderung berhatihati dalam menggunakan utang, temuan ini sejalan dengan konsep keagenan yang menyatakan bahwa kepemilikan saham oleh manajemen akan mengeleminasi konflik

JURNAL ILMIAH KOMPUTERISASI AKUNTANSI Vol. 14, No. 1, Juli 2021 : 186 - 195 
kepentingan antara pemilik dan manajemen, karena manajemen juga bagian dari pemilik prusahaan, Perilaku ini ditunjukan dalam penggunaan utang sebagai alternatif pembiayaan.

\subsection{Hubungan Kepemilikan saham Institusi dengan Struktur Modal.}

Hipotesis keterkaitan investor institusi dengan struktur modal $(\mathrm{H} 3)$ menyatakan bahwa investor institusi berpengaruh negatif terhadap struktur modal. Hasil uji hipotesis menunjukan bahwa investor institusi berpengaruh positif signifikan terhadap struktur modal, hal ini bisa dilihat dari koefisien regresi INST 0,028 dengan nilai signikansi $0,000<0,05$. Hasil ini tidak berlawanan dengan prediksi sebelumnya yang dinyatakan dalam hipotesis (H3).Temuan ini dapat diinterpretasikan bahwa investor institusi cenderung mendorong manajemen untuk menggunakan utang dalam membiayai kegiatan operasional perusahaan, temuan ini bertentangan dengan penelitian sebelumnya yang menyatakan bahwa investor institusi berpengaruh negatif terhadap struktur modal [22;32;25]. Mengacu pada konsep free cash flow, yang menyatakan bahwa ada kecenderungan manajemen suka menggunakan kas bebas tersebut untuk investasi yang tidak efisien, untuk itu manajemen perlu didisiplinkan dengan penggunaan utang, untuk dipaksa membayar pokok dan bunga [38].

\section{Tabel III}

Hasil Uji Hipotesis Model (1)

\begin{tabular}{|c|c|c|c|c|c|}
\hline \multirow[t]{2}{*}{ Variabel } & \multicolumn{2}{|c|}{$\begin{array}{c}\text { Unstandardized } \\
\text { Coefficients }\end{array}$} & \multirow{2}{*}{$\begin{array}{c}\text { Standardized } \\
\text { Coeffcients } \\
\text { Beta }\end{array}$} & \multirow[t]{2}{*}{$\mathrm{t}$} & \multirow[t]{2}{*}{ sig } \\
\hline & B & Std Error & & & \\
\hline Constant & 0,378 & 0,403 & & 0,938 & 0,351 \\
\hline INSD & 0,052 & 0,239 & 0,231 & $-2,239$ & 0,028 \\
\hline INST & 0,028 & 0,008 & 0,382 & 3,692 & 0,000 \\
\hline
\end{tabular}

Sumber: data diolah

\subsection{Hubungan Kepemilkan Saham Manajemen dengan Nilai Perusahaan.}

Hubungan kepemilikan saham manajemen dengan nilai perusahaan diprediksi berpengaruh positif terhadap nilai perusahaan seperti dinyatakan dalam hopotesis (H2), logika hubungan ini sebagai mana dijelaskan dalam konsep keagenan. Tabel IV merupakan hasil uji regresi model (2) yang menguji variabel yang diprediksi mempengaruhi nilai perusahaan. Hasil uji hepotesis keterkaitan kepemilikan saham manajemen (INSD) terhadap nilai perusahaan (Q) menunjukan hasil sesui yng diprediksikan hal ini bisa dilihat nilai koefisien 0,016 dengan nilai signifikansi 0,000 $<0,05$, hasil temuan ini mendukung penelitian sebelumnya yang dilakukan oleh [26;17], hasil ini juga mendukung konsep keagenan sebagaimanatelah dijelaskan, kepemilikan saham manajemen sebagai cara memotivasi manajemen untuk bertindak sebagai pemilik sehingga berdampak positif pada nilai perusahaan, sebagai cerminan harga saham.

\subsection{Hubungan kepemilikan saham Institusi dengan Nilai Perusahaan.}

Penelitian ini memprediksi kepemilikan saham oleh investor institusi berpengaruh positif terhadap nilai perusahaan seperti yang dinyatakan dalam Hipotesis $(\mathrm{H} 4)$, prediksi ini atas dasar bahwa investor institusi memiliki kemampuan pengawasan yang lebih efektif bila dibanding dengan investor lain. Berdasarkan hasil uji hepotesis seperti terlihat pada Tabel IV, bahwa investor institusi berpengaruh negatif terhadap nilai perusahaan, hal ini bisa dilihat dari nilai koefisien regresi INST -0,013 dengan signifikansi 0,000 , hasil berlawanan dengan prediksi sebelumnya yang menyatakan bahwa investor institusi berpengaruh positif terhadap nilai perusahaan. hasil penelitian ini bertentangan dengan penelitian sebelumnya yang menemukan pengaruh positif investor institusi dengan nilai perusahaan [25; 36]. Temuan ini cukup mengejutkan karena seperti telah kita ketahui investor institusi adalah investor yang memiliki kekuatan yang dapat mengontrol secara efektif serta ikut berperan dalam menentukan portofolio perusahaan sebagaimana dijelaskan [25]. Hasil temuan ini sejalan dengan penelitian sebelumnya yang dilakukan oleh [44], dalam penelitianya memisahkan kepemilikan asing

KETERKAITAN STRUKTUR KEPEMILIKAN, STRUKTUR MODAL DAN NILAI PERUSAHAAN 
(foreign ownership), Kepemilikan saham negara (Goverment ownership), dan investor institusi, dan hasilnya menemukan bahwa investor instutusi berpengaruh negatif terhadap nilai perusahaan.

\subsection{Hubungan Struktur Modal dengan Nilai Perusahaan.}

Hubungan struktur modal dengan nilai perusahaan diprediksi berpengaruh positif terhadap nilai perusahaan seperti yang dinyatakan dalam hipotesis (H5). Hubungan berdasarkan Signaling theory, bahwa pemegang saham luar dan manajemen tidak memiliki akses informasi yang sama, adanya informasi yang tidak simetris (asymetric information) tersebut. ketika diterbitkan utang baru direspon oleh pemegang saham sebagai signal prospek yang positif yang dapat meningkatkan nilai perusahaan[39]. Berdasarkan hasil uji hipotesis seperti terlihat dalam Tabel IV menunjukan koefisien regresi 0,129 dengan nilai signifikansi $0,000<0,05$, nilai ini menunjukan bahwa secara statistik struktur modal (CAPS) berpengaruh positif terhadap Nilai perusahaan (Q). Temuan ini mendukung signaling theory, dan penelitian sebelumnya yang menyatakan bahwa kebijakan struktur berpengaruh positif terhadap nilai perusahaan $[34 ; 35 ; 36]$.

Tabel IV

Hasil Regresi model (2)

\begin{tabular}{crrrrr}
\hline \multirow{2}{*}{ Variabel } & \multicolumn{2}{c}{$\begin{array}{l}\text { Unstandardized } \\
\text { Coefficients }\end{array}$} & $\begin{array}{c}\text { Standardized } \\
\text { Coeffcients }\end{array}$ & \multirow{2}{*}{$\mathrm{t}$} & \multirow{2}{*}{ sig } \\
\cline { 2 - 4 } & \multicolumn{1}{c}{$\mathrm{B}$} & \multicolumn{1}{c}{ Std Error } & & & \\
\hline Constant & 0,997 & 0,101 & & 8,750 & 0,000 \\
INSD & 0.016 & 0,006 & 0,282 & 2,800 & 0,006 \\
INST & $-0,013$ & 0,002 & $-0,529$ & $-4,945$ & 0,000 \\
CAPS & 0,129 & 0,026 & 0,411 & 3,840 & 0,000
\end{tabular}

Dependent variable : $Q$

Sumber: Data diolah

3.6. Hubungan Struktur kepemilikan (ISND,INST), Struktur Modal, dan Nilai Perusahaan.

Penelitian ini menempatkan variabel struktur modal (CAPS) sebagai variabel yang memediasi hubungan kepemilkan saham manejemen (INSD), dan Kepemilikan saham institusi (INST) dengan nilai perusahaan. berdasarkan hasil uji hubungan tersebut seperti terlhat dalam Tabel V, meninjukan bahwa struktur modal sebagai variabel yang memediasi hubungan kepemilikan saham manajemen (INSD) dengan nilai perusahaan (Q), hal ini bisa dilihat dari nilai statistik 1,93422015 dengan $P$ value 0,04713268 < 0,05. Selanjutnya, Hasil uji statistik menunjukan bahwa struktur modal (CAPS) bukan merupakan variabel medisi hubungan kepemilikan saham institusi (INST) dengan nilai perusahaan (Q), hal ini bisa dilihat nilai statistik 0,380112376 dengan $p$ value $0,70385355>0,05$. Dengan demikian hasil uji statistik ini menyimpulkan bahwa struktur modal merupakan varibel yang memediasi hubungan kepemilikan saham manajemen dengan nilai perusahaan.

Tabel V

Hasil Uji Mediasi

\begin{tabular}{lccccc}
\hline No & \multicolumn{3}{c}{ Variabel } & \multicolumn{2}{c}{ Sobel test } \\
\cline { 2 - 6 } & independen & Mediasi & Dependen & Statistic & $P$ value \\
\hline 1 & ISND & CAPS & $\mathrm{Q}$ & 1.93422015 & 0.04713268 \\
2 & ISNT & CAPS & $\mathrm{Q}$ & 0,38012376 & 0,70385355 \\
\hline
\end{tabular}

Sumber: data diolah

\section{Kesimpulan.}

Berdasarkan hasil uji hipotesis dan pembahasan hubungan struktur kepemilikan dengan kebijakan struktur modal dapat disimpulkan bahwa, kepemilikan saham manajemen (Management ownership), dan kepemilikan saham institusi (Institution ownershi),secara statistik JURNAL ILMIAH KOMPUTERISASI AKUNTANSI Vol. 14, No. 1, Juli 2021 : 186 - 195 
terbukti mempengaruhi struktur modal, akan tetapi kepemilkan saham institusi koefisien arahnya berlawanan dengan yang diprediksi sebelumnya yaitu arahnya negatif. Hasil temuan ini mengindikasikan bahwa investor insitusi lebih menghendaki penggunaan utang dalam pembiayaan perusahaan, dengan penggunaan utang tersebut proporsi kepemilikan bisa dipertahankan. Berdasarkan hasil uji hipotesis faktor yang diprediksi mempengaruhi nilai perusahaan, tiga variabel yang dirediksi mempengaruhi nilai perusahaan yaitu, Kepemilikan saham manajemen, kepemilikan saham institusi dan struktur modal secara statitistik semua mempengaruhi nilai perususahaan secara signifikan, namun kepemilkan saham institusi arahnya negatif, berlawanan denga yang diprediksikan. Temuan ini cukup mengejutka karena investor institusi ini pada umumnya secara efektif ikut mengawasi keputusan yang dilakukan oleh manajemen termasuk dalam menentukan portofolio bisnis, pada perusahaan sub sektor industri dasar dan Kimia tidak terbukti. Berdasarkan hasil uji mediasi menunjukan bahwa struktur modal merupakan varibel yang memediasi hubungan kepemilikan saham manajemen dengan nilai perusahaan.

Hasil penelitian ini memberi kontribusi mendukung Agency Theory dan Signaling Theory yang terkait dengan kepemilakan saham manajemen dan kebijakan utang.

Penelitian ini memiliki keterbatasan yang terkait dengan pengukuran variabel invetor institusi yang tidak memisahkan koponen kepemilikan saham institusi, yang mempunyai karekteristik dan kepentingan yang tidak sama, oleh karena itu, penelitian ini merekomendasikan penelitian berikutnya untuk memisahkan investor unstitusi sesuai dengan tujuan dan karakteristiknya.

\section{Daftar Pustaka.}

[1] Brigham EF. Brigham, Eugene F._Houston, Joel F. - Fundamentals of financial management-Cengage Learning (2020).pdf.

[2] Modigliani F, Miller MH. Income Taxes and the Cost of Capital. Am Econ Rev 1963; 53: 433-443.

[3] Stiglitz JE. of the Miller Theoremn. Am Econ Rev 1969; 59: 784-793.

[4] Ali A, Faisal S. Capital structure and financial performance: A case of saudi petrochemical industry. J Asian Financ Econ Bus 2020; 7: 105-112.

[5] Myers SC. Determinants of corporate borrowing. J financ econ 1977; 5: 147-175.

[6] Myers SC, Majluf NS. Corporate financing and investment decisions when firms have information that investors do not have. J financ econ 1984; 13: 187-221.

[7] Subagyo $\mathrm{H}$. Efektifitas kebijakan struktur modal dalam meningkatkan nilai perusahaan. $J$ Bisnis dan Ekon 2011; 18: 59-68.

[8] Nejad NR, Wasiuzzaman S. Multilevel Determinants of Capital Structure: Evidence from Malaysia. Glob Bus Rev 2015; 16: 199-212.

[9] Edmans A. Blockholders and corporate governance. Annu Rev Financ Econ 2014; 6: 23-50.

[10] Borochin P, Yang J, Zhang R. The Effect of Institutional Ownership Types on Innovation and Competition. SSRN Electron J. Epub ahead of print 2018. DOI: 10.2139/ssrn.3204767.

[11] Brooks C, Chen Z, Zeng Y. Institutional cross-ownership and corporate strategy: The case of mergers and acquisitions. J Corp Financ 2018; 48: 187-216.

[12] Kostovetsky L, Manconi A. Common Institutional Ownership and Diffusion of Innovation. SSRN Electron J. Epub ahead of print 2018. DOI: 10.2139/ssrn.2896372.

[13] Jensen MC, Meckling WH. Theory of the firm: Managerial behavior, agency costs and ownership structure. J financ econ 1976; 3: 305-360.

[14] Fayez M, Ragab AA, Moustafasoliman M. The Impact of Ownership Structure on Capital Structure: An Empirical Study on the Most Active Firms in the Egyptian Stock Exchange. OALib 2019; 06: 1-13.

[15] Subiantoro S. Pengaruh Struktur Kepemilikan, Strategi Diversifikasi, Leverage, Faktor Intern Dan Faktor Ekstern Terhadap Nilai Perusahaan (Studi Empirik Pada Perusahaan Manufaktur Dan Non Manufaktur Di Bursa Efek Jakarta). Manaj dan Kewirausahaan

KETERKAITAN STRUKTUR KEPEMILIKAN, STRUKTUR MODAL DAN NILAI PERUSAHAAN 
2007; 9: 41-48.

[16] Muñoz Mendoza JA, Sepúlveda Yelpo SM, Veloso Ramos CL. Non-linear Effects of Ownership Structure, Growth Opportunities and Leverage on Debt Maturity in Chilean Firms. Rev Mex Econ y Finanz 2019; 14: 21-40.

[17] Santi Novita MS. Ownership Structure, Firm Value and Mediating Effect of Firm Performance. J Akunt 2020; 24: 219.

[18] Kusumastuti S, Supatmi, Sastra P. Pengaruh Board Diversity Terhadap Nilai Perusahaan Dalam Perspektif Corporate Governance. J Akunt dan Keuang 2014; 9: 8898.

[19] Din SU, Arshad Khan M, Khan MJ, et al. Ownership structure and corporate financial performance in an emerging market: a dynamic panel data analysis. Int $\mathrm{J}$ Emerg Mark. Epub ahead of print 2021. DOI: 10.1108/IJOEM-03-2019-0220.

[20] Shyu J. Ownership structure, capital structure, and performance of group affiliation: Evidence from Taiwanese group-affiliated firms. Manag Financ 2013; 39: 404-420.

[21] Bemby S. B, Mukhtaruddin, Hakiki A, et al. Intellectual capital,firm value and ownership structure as moderating variable: Empirical study on banking listed in indonesia stock exchange period 2009-2012. Asian Soc Sci; 11. Epub ahead of print 2015. DOI: 10.5539/ass.v11n16p148.

[22] Alwi S, Rahim RA. Dividend and debt policy as corporate governance mechanism: Indonesian evidence. J Pengur 2009; 29: 111-125.

[23] Fahlenbrach R, Stulz RM. Managerial ownership dynamics and firm value. J financ econ 2009; 92: 342-361.

[24] Ling YH, Jaw BS. The influence of international human capital on global initiatives and financial performance. Int J Hum Resour Manag 2006; 17: 379-398.

[25] KASABOĞLU OT, ÇINKO M. a Study of the Relationship Between Institutional Ownership and Capital Structure: Evidence From Turkey. Marmara J Econ 2017; 1: 155-170.

[26] Pirzada K, Mustapha MZ Bin, Wickramasinghe D. Firm Performance, Institutional Ownership and Capital Structure: A Case of Malaysia. Procedia - Soc Behav Sci 2015; 211: 170-176.

[27] SOLIKHAH B, WAHYUDIN A, RAHMAYANTI AAW. The Extent of Intellectual Capital Disclosure and Corporate Governance Mechanism to Increase Market Value. J Asian Financ Econ Bus 2020; 7: 119-128.

[28] Rohim M, Syamsudin, Satriawi SPW. The effect of ownership structure on firm value with profitability as a moderating variabel. J Apl Manaj 2019; 18: 122-129.

[29] Trafalgar J, Africa LA. The effect of capital structure, institutional ownership, managerial ownership, and profitability on company value in manufacturing companies. Indones Account Rev 2019; 9: 27.

[30] Choi PMS, Choi JH, Chung CY, et al. Corporate governance and capital structure: Evidence from sustainable institutional ownership. Sustain 2020; 12: 1-8.

[31] Shleifer A, Vishny RW. The limits of arbitrage. Adv Behav Financ 1997; 2: 79-101.

[32] Hansen RS, Crutchley CE. Agency Theory of Corporate Ownership , Managerial Corporate Dividends Leverage , and Corporate Dividends. Financ Manag 1989; 18: $36-$ 46.

[33] Persson R. Simultaneous determination of Debt, Dividend, and Inside Ownership policies: Evidence from Sweden.

[34] Vo DH, Nguyen VT-Y. Managerial Ownership, Leverage and Dividend Policies: Empirical Evidence from Vietnam's Listed Firms. Int J Econ Financ; 6. Epub ahead of print 2014. DOI: 10.5539/ijef.v6n5p274.

[35] Joher H, Ali M, Nazrul M. The Impact Of Ownership Structure On Corporate Debt Policy: Two Stage Least Square Simultaneous Model Approach For Post Crisis Period: Evidence From Kuala Lumpur Stock Exchange. Int Bus Econ Res J 2011; 5: 51-64.

[36] Handriani E, Robiyanto R. Institutional ownership, independent board, the board size, and firm performance: Evidence from Indonesia. Contaduria y Adm 2018; 64: 1-16.

[37] Kakilli AS. The determinants of capital structure: Evidence from the Turkish manufacturing sector. Int J Econ Financ Issues 2015; 5: 158-171. 
[38] Jensen MC. Journal of Social and Personal. J Soc Pers Relatsh 1986; 15: 755-773.

[39] stephen A.Ross. The Determination of Financial Structure: The Incentive-Signalling Approach. Bell J Econ 1997; 8: 23-40.

[40] Aggarwal D, Padhan PC. Impact of Capital Structure on Firm Value: Evidence from Indian Hospitality Industry. Theor Econ Lett 2017; 07: 982-1000.

[41] Sari IAGDM. Profitability and liquidity on firm value and capital structure as intervening variable. Int Res J Manag IT Soc Sci 2020; 7: 116-127.

[42] Uzliawati L, Yuliana A, Januarsi Y, et al. Optimisation of capital structure and firm value. Eur Res Stud J 2018; 21: 705-713.

[43] Kayhan A, Titman S. Firms' Histories and Their Capital Structures. SSRN Electron J. Epub ahead of print 1984. DOI: 10.2139/ssrn.552144.

[44] L.I Wijaya, Welson \& WRM, University of Surabaya, Surabaya I. Ownership Structure, Good Corporate Governance, and Firm Performance in the Indonesian Capital Market. Adv Econ Bus Manag Res Vol 115 17th Int Symp Manag (INSYMA 2020) 2020; 15: 256-260. 